\section{PHYSICAL ACTIVITY LEVEL AND SEDENTARY BEHAVIOR OF MILITARY POLICE STAFF}

\author{
NIVELL DE ATIVIDADE FISICA E COMPORTAMENTO SEDENTÁRIO DE POLICIAIS MILITARES
}

NIVEL DEACTIVIDAD FÍSICA Y COMPORTAMIENTO SEDENTARIO DE POLICÍAS MILITARES

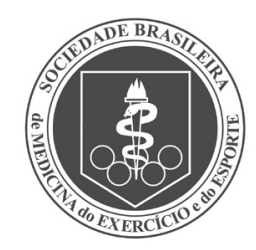

Original Article

Artigo Original Artículo Original

\section{Almir de França Ferraz 1,2 (ID) (Physical Education Professional and Military Police Officer) \\ Erinaldo Luiz de Andrade ${ }^{3}$ (DD (Physical Education Professional) Michell Vetoraci Viana ${ }^{1}$ (ID (Physical Education Professional) Roberta Luksevicius Rica ${ }^{4}$ (DD (Physical Education Professional) Danilo Sales Bocalini ${ }^{5}$ (ID) (Physical Education Professional) Aylton Figueira Júnior ${ }^{1}$ (D) (Physical Education Professional)}

1. Universidade São Judas Tadeu (USJT), Department of Graduate Studies in Physical Education, São Paulo, SP, Brazil.

2. Diretoria de Ensino, Instrução e Pesquisa da Polícia Militar do Estado de Mato Grosso, MT, Brazil.

3. Universidade Nove de Julho (UNINOVE), São Paulo, SP, Brazil. 4. Universidade Estácio de Sá (UNESA), Department of Physical Education, ES, Brazil.

5. Universidade Federal do Espírito Santo, Laboratory of Physiology and Experimental Biochemistry, Center for Physical Education and Sports, Vitória, ES, Brazil.

\section{Correspondence:}

Almir de França Ferraz.

Rua Taquari, 546, Mooca, São Paulo, SP, Brazil. 03166-000.

Ferraz7777@gmail.com

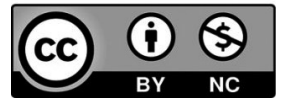

\section{ABSTRACT}

Introduction: Studies of sedentary behavior in the workplace, where conditions represent a health risk, mainly involving levels of physical activity and health of police officers, have increased in several countries around the world. Objective The objective of this study was to compare the physical activity levels, sedentary behavior and health risks of military police officers involved in overt and specialized patrolling. Methods: A total of 146 military police officers involved in overt and specialized patrolling were assessed, and anthropometric data were collected for body mass - kg; height - $\mathrm{m} ; \mathrm{BMI}-\mathrm{kg} / \mathrm{m}^{2}$; waist-hip ratio (WHR) and fat percentage. Physical activity and inactivity levels were determined using the International Physical Activity Questionnaire (IPAQ), short version 8, with statistical analysis (t-Test, Mann-Whitney $\mathrm{U}$ test and Chi-squared test, $\mathrm{p} \leq 0.05$ ). Results: The mean time of physical activity - overt patrolling (108.33 $\pm 92.60 \mathrm{~min} /$ week) and specialized patrolling (137.11 $\pm 90.30 \mathrm{~min} /$ week) totaled an overall mean of $122.72 \pm 91.94 \mathrm{~min} /$ week, $\mathrm{p} \leq 0.05$; and time seated - overt patrolling (391.27 $\pm 192.90 \mathrm{~min} /$ week) had $30.1 \%$ of insufficiently active participants, while specialized patrolling was $319.41 \pm 123.10 \mathrm{~min} /$ week with $17.1 \%$ of insufficiently active participants, with a total mean of $312.00 \pm 112.30 \mathrm{~min} /$ week and $47.3 \%$ of insufficiently active participants. Active police officers are one-third less likely to develop health risk than inactive police officers ( $\mathrm{OR}=0.3, \mathrm{Cl}=0.18-0.67)$. Overt patrol police officers are 3.6 more likely to develop health risk than specialized patrol police officers due to sedentary behavior $(\mathrm{OR}=3.6, \mathrm{Cl}=1.48-8.75)$. Conclusion: Both groups of military police officers have lower than recommended physical activity levels and spend most of their time seated. It was also noted that the variables of overt patrol police officers have indicators that are more detrimental to health than specialized patrol officers, yet both occupational groups should be instructed on how to adopt active and healthy lifestyles. Level of evidence Il; Prognostic studies-Investigation of the effect of patient characteristics on disease outcome.

Keywords: Police; Physical activity; Sedentary behavior; Risk; Health.

\section{RESUMO}

Introdução: Estudos sobre o comportamento sedentário no ambiente laboral, cujas condições são de risco à saúde, principalmente, envolvendo níveis de atividade física e saúde de policiais, aumentaram em diversos países do mundo. Objetivo: O objetivo do presente estudo foi comparar os níveis de atividade física, o comportamento sedentário e os riscos à saúde de policiais militares do patrulhamento ostensivo e do especializado. Métodos: Foram avaliados 146 policiais militares do patrulhamento ostensivo e do especializado e coletados dados antropométricos de massa corporal - kg; estatura - m; IMC - kg/m²; relação cintura/quadril (RCQ) e percentual de gordura. Os níveis de atividade e de inatividade física foram determinados pelo IPAQ, versão curta 8, com análise estatística (teste T, U de Mann-Whitney e Qui-quadrado, $p \leq 0,05$ ). Resultados: O tempo médio de atividade física - patrulhamento ostensivo $(108,33 \pm 92,60 \mathrm{~min} / \mathrm{sem})$ e do especializado $(137,11 \pm 90,30 \mathrm{~min} / \mathrm{sem})$ totalizou na média geral 122,72 $\pm 91,94 \mathrm{~min} / \mathrm{sem}$, p $\leq 0,05$; e o tempo sentado - patrulhamento ostensivo $(391,27 \pm 192,90 \mathrm{~min} / \mathrm{sem}) \mathrm{com} 30,1 \%$ de insuficientemente ativos e do especializado $(319,41 \pm 123,10 \mathrm{~min} / \mathrm{sem}) \mathrm{com} 17,1 \%$ de insuficientemente ativos, alcançando a média total de $312,00 \pm 112,30 \mathrm{~min} / \mathrm{sem}$ e $47,3 \%$ de insuficientemente ativos. Os policiais ativos têm um terço a menos de chance de desenvolver risco à saúde que os inativos $(O R=0,3 ; / C=0,18-0,67)$. Os policiais do patrulhamento ostensivo possuem mais chances $(3,6)$ de risco à saúde que os especializados devido ao comportamento sedentário (OR=3,6; IC=1,488,75). Conclusão: Ambos os grupos de policiais militares possuem níveis de atividade física abaixo do recomendado e passam a maior parte tempo na posição sentada. Observou-se também que as variáveis dos policiais do patrulhamento ostensivo possuem indicadores mais prejudiciais à saúde do que as dos especializados, entretanto, ambos os grupos ocupacionais devem ser orientados sobre adoção de estilos de vida ativo e saudável. Nível de evidência Il; Estudos prognósticos-Investigação do efeito de característica de um paciente sobre o desfecho da doença.

Descritores: Policia; Atividade física; Comportamento sedentário; Risco; Saúde.

\section{RESUMEN}

Introducción: Los estudios sobre el comportamiento sedentario en el ambiente laboral, cuyas condiciones son de riesgo a la salud, principalmente involucrando niveles de actividad física y salud de policías aumentaron en diversos países del mundo. Objetivo: El objetivo del presente estudio fue comparar los niveles de actividad física, el comportamiento sedentario y los riesgos para la salud de policías militares de la ronda ostensiva y especializada. Métodos: 
Fueron evaluados 146 policías militares de la ronda ostensiva y especializada y colectados datos antropométricos de la masa corporal - kg; estatura - m; IMC - kg/m²; relación cintura/cadera (RCQ) y porcentaje de grasa. Los niveles de actividad e inactividad fisica fueron determinados por IPAQ, versión corta 8, con análisis estadístico (test T, U de Mann-Whitney y Chi-cuadrado, $p \leq 0,05)$. Resultados: El tiempo promedio de actividad física-ronda ostensiva (108,33 \pm $92,60 \mathrm{~min} / \mathrm{sem})$ y de la especializada $(137,11 \pm 90,30 \mathrm{~min} / \mathrm{sem})$, totalizó en el promedio general $122,72 \pm 91,94 \mathrm{~min} / \mathrm{sem}$, p $\leq 0,05$; y el tiempo sentado - ronda ostensiva $(391,27 \pm 192,90 \mathrm{~min} / \mathrm{sem})$ con $30,1 \%$ de insuficientemente activos y de la especializada $(319,41 \pm 123,10 \mathrm{~min} / \mathrm{sem})$ con $17,1 \%$ de insuficientemente activos, alcanzando el promedio total de 312,00 $\pm 112,30 \mathrm{~min} / \mathrm{sem}$ y 47,3\% de insuficientemente activos. Los policías activos tienen un tercio menos de probabilidad de desarrollar riesgo a la salud que los policías inactivos $(O R=0,3, I C=0,18-0,67)$. Los policías de la ronda ostensiva poseen más chances $(3,6)$ de riesgo a la salud que los especializados debido al comportamiento sedentario $(O R=3,6, I C=1,48-8,75)$. Conclusión: Ambos grupos de policías militares poseen niveles de actividad física por debajo de lo recomendado y pasan la mayor parte del tiempo sentados. Se observó también que las variables de los policías de la ronda ostensiva poseen indicadores más nocivos para la salud que los especializados, entretanto, ambos grupos ocupacionales deben ser orientados sobre la adopción de estilos de vida activos y saludables.

Nivel de evidencia Il; Estudios pronósticos-Investigación del efecto de característica de un paciente sobre el desenlace de la enfermedad.

Descriptores: Policia; Actividad física; Conducta sedentaria; Riesgo; Salud.

\section{INTRODUCTION}

Police officers are legally constituted authorities who perform their duties in uniform or wearing plainclothes. Military police undertake overt operations and are equipped to maintain public order. ${ }^{1}$ The different police functions are established by the specificity of the service: overt patrolling (policing on foot, by car, bicycle or motorcycle) and specialized patrolling (policing of special operations, tactical actions, mounted police, road policing and others). ${ }^{1}$

Overt patrol officers are stationed in the ordinary battalions responsible for security and maintaining the order (external community service), while specialized patrol officers are usually based in barracks, have no delimited area and undertake highly complex tactical actions.

Although police institutions have internal regulations for physical activity, it can be noted that there are professionals with high rates of active insufficiency, which lead to the occurrence of injuries and the development of chronic diseases that can affect both their health and work. These individuals fall into the risk group. ${ }^{1,2}$

The environment of a police institution can contribute to the development of sedentary behavior. Therefore, it is important to make the entire team aware of the benefits of physical activity, which are related to health, well-being, prevention and reduction of cardiometabolic diseases. . $^{3-5}$

The occupational activity of military police officers, who are often patrolling while seated in vehicles or inside barracks, presents environmental conditions that can bring about the process of physical inactivity. The negative effect of physical inactivity is found in various occupational groups. $^{6-8}$ Accordingly, in this study we sought to verify whether the effect also occurs in the group of law enforcement officers.

Physical inactivity can impact the performance of police functions since adopting a sedentary lifestyle can be detrimental to the health of these professionals. However, if action is taken to raise awareness in this population with the implementation of mechanisms that improve fitness, the development of pathologies in police officers can be reduced. ${ }^{9-11}$ Regular physical activity and good fitness levels can control or prevent the development of chronic diseases. ${ }^{3}$

The aim of this study is to compare the level of physical activity, sedentary behavior and health risks of military police officers involved in overt and specialized patrolling.

\section{MATERIALS AND METHODS}

A total of 146 military police officers from two battalions in the city of Cuiabá, Brazil (overt patrols, $n=73$ and specialized patrols, $n=73$ ), all male, were assessed. The participants enrolled in the study were military police officers on active duty (who make up the duly appointed staff), while those who did not agree to participate in the study or who had a problem that prevented them from undertaking the collection procedures were excluded. Sample characteristics are described by job title and rank in Table 1.

Institutional consent and approval of the Institutional Review Board of Universidade São Judas Tadeu (USJT) were granted through opinion No. 1,327,771, on November 18, 2015. Military police officers participated in the research project voluntarily, after viewing the Informed Consent Form (ICF). This was followed by the data collection.

Body mass, height and Body Mass Index (BMI) were measured using a digital scale with an attached stadiometer. To obtain the waist-hip ratio (WHR), abdominal, waist and hip circumference measurements were collected using a measuring tape, and subjects were classified as eutrophic $\left(<25 \mathrm{~kg} / \mathrm{m}^{2}\right)$ or overweight $\left(\geq 25.0 \mathrm{~kg} / \mathrm{m}^{2}\right)$ in terms of BMl and fat percentage. Fat percentage was determined considering seven skinfolds: subscapular, triceps, biceps, chest, midaxillary, suprailiac, abdomen and thigh, using the Sanny ${ }^{\circledR}$ adipometer and establishing the level of adiposity. ${ }^{12,13}$

Table 1. Military police officers organized by seniority.

\begin{tabular}{|c|c|c|c|}
\hline & $\begin{array}{c}\text { Overt patrolling } \\
\mathrm{n}(\%)\end{array}$ & $\begin{array}{c}\text { Specialized } \\
\text { n (\%) }\end{array}$ & $\begin{array}{l}\text { Total } \\
\text { n (\%) }\end{array}$ \\
\hline Enlisted ranks & $65(89.0)$ & $66(90.4)$ & $130(89.7)^{* *}$ \\
\hline Private & $37(49.3)$ & $24(32.9)$ & $60(41.1)$ \\
\hline Corporal & $16(21.9)$ & $23(31.5)$ & $39(26.7)$ \\
\hline Sergeant & $11(15.1)$ & $13(17.8)$ & $24(16.4)$ \\
\hline Sub-lieutenant & $1(1.4)$ & $6(8.2)$ & $7(4.8)$ \\
\hline Commissioned officers & $8(11.0)$ & $7(9.6)$ & $15(10.3)$ \\
\hline Lieutenant & $5(6.8)$ & $2(2.7)$ & $7(4.8)$ \\
\hline Captain & $1(1.4)$ & $3(4.1)$ & $4(2.7)$ \\
\hline Major & $2(2.7)$ & $2(2.7)$ & $4(2.7)$ \\
\hline Lieutenant-Colonel & $1(1.4)$ & $0(0.0)$ & $1(0.7)$ \\
\hline Total & $73(100)$ & $73(100)$ & $146(100)^{* *}$ \\
\hline
\end{tabular}


The protocol for estimating the level of physical activity was performed using the International Physical Activity Questionnaire (IPAQ) short version 8. The IPAQ enabled us to classify participants in different categories of physical activity (very active, active, irregularly active, sedentary) and as "active" and "insufficiently active" / inactive", according to the recommendation of 150 minutes per week of physical activity. ${ }^{14,15}$

To measure time in a sitting position and to assess sedentary behavior, we used the adapted method of Katzmarzyk et al. ${ }^{16}$ This protocol classifies people's physical inactivity levels into five categories, namely: (a) shortest part of the day; (b) $1 / 4$ of the day; (c) half of the day; (d) 3/4 of the day; and (e) most of the day, and can also estimate the participants' health risks.

\section{Statistical analyses}

SPSS 22.0 software was used and data normality was tested by the Kolmogorov-Smirnov test, with a significance level of 95\% ( $p<0.05)$. Data are expressed as mean, $( \pm)$ standard deviation, absolute frequency in number (n), and relative frequency in percentage (\%). The sample was distributed into two police groups (overt patrolling and specialized patrolling) to perform statistical analysis of comparisons of mean physical activity levels, anthropometric measurements and body composition using the t-test or Mann Whitney $U$ test and associations using the Chi-squared test.

\section{RESULTS}

The means obtained in each of the groups studied, were: (1) overt patrolling: age $31 \pm 7$ years, body mass $86.4 \pm 14.3 \mathrm{~kg}$ and height $1.76 \pm$ $0.70 \mathrm{~m}$; and (2) specialized patrolling: age $34 \pm 7$ years, body mass 84.9 $\pm 12.8 \mathrm{~kg}$ and height $1.76 \pm 0.63 \mathrm{~m}$; and the sample means were: age 33 \pm 7 years, body mass $85.7 \pm 13.6 \mathrm{~kg}$ and height $1.76 \pm 0.06 \mathrm{~m}$. (Table 2)

Privates and corporals represent the majority of the sample $(41.1 \%$ and $26.7 \%$, respectively), and are called "enlisted ranks"; while the smaller proportion is made up of the various officers. This considerable difference in the proportion of ranks between participants is explained by the hierarchical structure of the institution.

The concentration in the age group is between 20 and 39 years; in length of service, between 11 and 20 years; in duty shift, between eight and 12 hours with statistical differences between groups $(p \leq 0.05)$. The participants are of middle socioeconomic status.

Table 3 shows the comparative data on the cumulative time of physical inactivity and physical activity of the police groups divided into three stratifications: (1) duties, (2) type of service, and (3) military positions.

Table 2. Characteristics of the groups of overt and specialized patrol officers.

\begin{tabular}{|c|c|c|c|c|}
\hline Variables & Overt & Specialized & Total & $p$ \\
\hline & $\mathrm{n}(\%)$ & $\mathrm{n}(\%)$ & $n(\%)$ & \\
\hline \multicolumn{5}{|l|}{ Age group } \\
\hline $20-29$ years & $43(29.5)$ & $37(25.3)$ & $80(54.8)$ & \multirow{4}{*}{$0.05^{*}$} \\
\hline 30-39 years & $30(20.5)$ & $36(24.7)$ & $66(45.2)$ & \\
\hline 40-> years & 14(9.6) & 19(13.0) & $33(22.6)$ & \\
\hline \multicolumn{4}{|l|}{ Length of service } & \\
\hline$\leq 10$ years & $38(26.0)$ & $26(17.8)$ & $64(43.8)$ & \multirow{2}{*}{$0.04^{*}$} \\
\hline$>20$ years & $35(24.0)$ & $47(32.2)$ & $82(56.2)$ & \\
\hline \multicolumn{5}{|l|}{ Type of role } \\
\hline Operational & $25(34.2)$ & $34(46.6)$ & $59(40.4)$ & \multirow{2}{*}{0.12} \\
\hline Administrative & 48(65.8) & $39(53.4)$ & $87(59.6)$ & \\
\hline \multicolumn{5}{|l|}{ Duty shifts } \\
\hline 8 and 12 hours & $73(100)$ & $44(60.3)$ & $117(80.1)$ & \multirow{2}{*}{0.00} \\
\hline$>12$ hours & $0(0.0)$ & 29(39.7) & 29(19.9) & \\
\hline \multicolumn{5}{|c|}{ Socioeconomic status } \\
\hline A1 (upper) & $9(6.2)$ & $7(4.8)$ & $16(11.0)$ & \multirow{2}{*}{$0.60^{* *}$} \\
\hline A2 (middle) & $64(43.8)$ & $66(45.2)$ & $130(89.0)$ & \\
\hline
\end{tabular}

In police functions, specialized professionals have longer accumulated time of physical activity (137.11 $\pm 90.30 \mathrm{~min} /$ week) than those working in overt patrolling (108.33 $\pm 92.56 \mathrm{~min} /$ week); however, this position is reversed when we compare accumulated sitting time, as overt patrolling officers have a higher mean (391.27 $\pm 192.86 \mathrm{~min} /$ week) than specialized patrolling officers (319.41 $\pm 123,10 \mathrm{~min} /$ week). Operational police officers (type of service), with a mean of $141.10 \pm 87.48$ and $356.32 \pm 170.41$, and officers (hierarchy) with a mean of $139.00 \pm 80.84$ and $351.84 \pm$ 166.44 , have the highest means of physical activity and sitting time (inactivity), in this order, compared to administrative staff and enlisted ranks, respectively.

Table 4 shows the categories of time of physical activity, sedentary behavior and its risk among military police officers working in overt patrolling and specialized military police.

$47.3 \%$ of the police were found to be insufficiently active, of which $30.1 \%$ corresponded to overt patrolling officers. Active officers (52.7\%) are one third (77.7\%) less likely to develop a health risk than insufficiently active officers. This significant difference is explained by the high level of sedentary behavior among insufficiently active police officers.

Table 5 associates active and insufficiently active/inactive military police officers with the condition of risk of adiposity.

High-risk sedentary behavior is present in $22.3 \%$ of the interviewees with a higher incidence among overt patrolling officers. This represents a 3.6x greater likelihood of health risk behavior than in specialized police officers (Table 4). It should be emphasized that the level of physical activity is not the predominant factor for risk reduction when associated with adiposity, and does not fully explain this phenomenon that reflects on the health or illness development process of military police officers.

\section{DISCUSSION}

Studies list the negative effects of a sedentary work environment that can affect the physical health of the population and occupational groups, causing the development of chronic cardiometabolic diseases. ${ }^{5,16,17}$ Approximately half of the sample was found to be sedentary, remaining seated for long periods throughout the day.

The high level of sedentary behavior is associated with health risks for various conditions of chronic disease development and premature mortality in people. ${ }^{4,18,19}$ Sitting for long hours reduces the life expectancy of individuals, the risk of dying increases 50 times among those who remain seated for long periods. ${ }^{16}$

The level of sedentary behavior affects most of the sample members in this research project, indicating that the overt patrolling category is three times more likely to have a health risk as a result of sedentary behavior, and twice as likely to be overweight and have low levels of physical activity than the other participants. These results can be explained by the lifestyle and occupational routine of these professionals. Specialized police officers have an in-house work regimen focused on physical and professional technical training to deal with highly complex external incidents, unlike overt patrolling officers who are involved in beat policing in various parts of the city. Specialized officers have a work organization that can include continuous physical and professional training, as opposed to overt patrolling officers, who depend on the organization of each battalion. These outcomes related to lifestyle and workplace routine are similar to the findings of Minayo et al. ${ }^{1}$

These factors indirectly interfere with the result that specialized police officers have physical activity levels that are closer to the recommended levels, and sedentary behavior levels are lower than in overt patrolling. Cross-sectional studies show that physically active US police officers are one third less likely to report back pain (OR 0.37, 95\% Cl 0.10-0.73), ${ }^{20}$ 
Table 3. Medial comparisons between time of (physical activity x physical inactivity) of the different positions, types of service and police hierarchical levels.

\begin{tabular}{|c|c|c|c|c|c|c|}
\hline \multirow{2}{*}{$\begin{array}{l}\text { Variables of physical } \\
\text { activity and inactivity }\end{array}$} & \multicolumn{6}{|c|}{ Specialized and overt patrol officers } \\
\hline & Overt patrolling & Specialized & Total & $p$ & $\mathrm{~T}$ & $\mathrm{Ci}(95 \%)$ \\
\hline Average time per position & $(\bar{x} \pm \mathrm{S})$ & $(\bar{X} \pm S)$ & $(\mathrm{x} \pm \mathrm{S})$ & & & \\
\hline $\mathrm{N}$ & 73 & 73 & 146 & & & \\
\hline $\mathrm{N}$ & 71 & 68 & 139 & & & \\
\hline Physical inactivity (min/day) & $391.27 \pm 192.86$ & $319.41 \pm 123.10$ & $312.00 \pm 112.30$ & $0.01^{*}$ & 2.61 & $17.76-125.96$ \\
\hline $\mathrm{N}$ & 87 & 59 & 146 & & & \\
\hline Physical activity (min/week) & $110.25 \pm 93.80$ & $141.10 \pm 87.48$ & $122.72 \pm 91.94$ & $0.04^{*}$ & 2.00 & $0.41-61.28$ \\
\hline $\mathrm{N}$ & 82 & 57 & 139 & & & \\
\hline Physical inactivity (min/day) & $356.00 \pm 160.70$ & $356.32 \pm 170.41$ & $312.00 \pm 112.30$ & 0.99 & 0.01 & $-55.88-56.56$ \\
\hline Average time by military role & \multicolumn{6}{|c|}{ Total } \\
\hline Physical inactivity (min/day) & $394.30 \pm 161.71$ & $351.84 \pm 166.44$ & $356.12 \pm 165.30$ & 0.36 & 0.91 & $-50.06-134.96$ \\
\hline
\end{tabular}

$\mathrm{n}=$ number of participants, $\mathrm{p}=\mathrm{p}$-value, $\mathrm{t}=\mathrm{T}$ test value, $\mathrm{Cl}=$ confidence interval, $(\overline{\mathrm{x}} \pm \mathrm{S})=$ mean \pm standard deviation, $\left({ }^{*}\right)=p<0.05$.

Table 4. Comparative association between sufficiency of physical activity, average time sitting (sedentary behavior) and risk to the health of police officers.

\begin{tabular}{|c|c|c|c|c|c|c|}
\hline $\begin{array}{c}\text { Sufficiency of } \\
\text { physical activity }\end{array}$ & $\begin{array}{c}\text { Overt } \\
\text { Patrolling }\end{array}$ & Specialized & Total & $p$ & OR & $\mathrm{Cl}(95 \%)$ \\
\hline Variables & $n(\%)$ & $n(\%)$ & $n(\%)$ & & & \\
\hline Active & 29(19.9) & $48(32.9)$ & $77(52.7)$ & & & \\
\hline Insufficiently active & $44(30.1)$ & $25(17.1)$ & $69(47.3)$ & $0.001^{*}$ & 0.34 & $0.17-0.67$ \\
\hline Total & $73(50.0)$ & $73(50.0)$ & $146(100)$ & & & \\
\hline Time sitting & $\begin{array}{c}\text { Overt } \\
\text { Patrolling }\end{array}$ & Specialized & Total & $p$ & OR & $\mathrm{Cl}(95 \%)$ \\
\hline $\begin{array}{l}\text { Shortest part } \\
\text { of the day }\end{array}$ & $23(74.2)$ & $8(25.8)$ & $31(22.3)$ & & & \\
\hline Most of the day & $48(44.4)$ & $60(55.6)$ & 108(3.6) & $0.001^{*}$ & 3.59 & $1.47-8.74$ \\
\hline Total & $71(51.1)$ & $68(48.9)$ & 139(100) & & & \\
\hline $\begin{array}{l}\text { Risk for average } \\
\text { time sitting }\end{array}$ & $\begin{array}{c}\text { Overt } \\
\text { Patrolling }\end{array}$ & Specialized & Total & $\mathrm{p}$ & OR & $\mathrm{Cl}(95 \%)$ \\
\hline $\begin{array}{c}\text { Greater likelihood } \\
\text { of risk }\end{array}$ & $23(16.5)$ & $8(5.8)$ & $31(22.3)$ & & & \\
\hline Less likelihood of risk & $48(34.5)$ & $60(43.2)$ & 108(77.7) & $0.001^{*}$ & 3.60 & $1.48-8.75$ \\
\hline Total & $71(51)$ & $68(49)$ & $139(100)$ & & & \\
\hline
\end{tabular}

$\mathrm{n}(\%)=$ number expressed in percentage, $p=p$-value, $\mathrm{OR}=$ Odds Ratio, $\mathrm{Cl}=$ confidence interval, $\left({ }^{*}\right)=p<0.05$.

Table 5. Association between fitness levels of police officers and their level of adiposity.

\begin{tabular}{c|c|c|c|c|c|c}
\hline Level of adiposity & Active & $\begin{array}{c}\text { Insufficiently active/ } \\
\text { inactive }\end{array}$ & Total & $\mathbf{p}$ & OR & $\mathbf{C l}$ \\
\hline & $\mathrm{n}(\%)$ & $\mathrm{n}(\%)$ & $\mathrm{n}(\%)$ & & & \\
\hline Risk & $61(41.8)$ & $29(19.9)$ & $90(61.9)$ & & & \\
\hline Normality & $27(18.5)$ & $29(19.9)$ & $56(38.4)$ & $0.02^{*}$ & 2.25 & $1.13-4.49$ \\
\hline Total & $88(60.3)$ & $58(39.7)$ & $146(100)$ & & & \\
\hline
\end{tabular}

$n(\%)=$ number expressed in percentage, $p=p$-value, $O R=$ Odds Ratio, $C l=$ confidence interval, $\left(^{*}\right)=p<0.05$.

and have physical activity levels associated with adiposity ${ }_{i}{ }^{21}$ in addition, when off duty they are more active than when on duty.,

In Brazil, there are negative influences that hinder the practice of physical activity by military police officers, of which the most obvious are family commitments and working hours, ${ }^{2}$ besides socio-environmental, psychological and internal institutional factors., ${ }^{1,23}$ Japanese law enforcement officers also have low levels of physical activity that, when combined with the stressful work, can lead to health risks for these professionals. ${ }^{24}$ The same is true for Indian police officers who have lower than recommended levels of physical activity, thus necessitating a lifestyle change..$^{25}$
Results of cross-sectional and longitudinal studies ${ }^{19,20,26-29}$ with European police officers show that the level of physical activity decreases over the years. These individuals were seen to work for long hours, which leads to a reduction in the level of physical activity, increased stress and adiposity. However, some longitudinal studies show that behavior change stimulates physical activity and reduces adiposity levels. ${ }^{26-29}$

Police institutions require physical fitness from their members to carry out their missions. However, the physical and mental strain involved in police activities - caused mainly by work shifts, strict compliance with hierarchy and discipline, high stress levels and incidents requiring police intervention that involve risk, as well as personal obligations s, $^{1,23}$ and the habit of spending long periods sitting in their vehicles, front counter jobs and in-house services, routine work activities - contributes to physical inactivity.

Police officers who continue with their sedentary behavior are very likely to acquire health risk factors resulting from unhealthy lifestyles that render them insufficiently active or inactive. ${ }^{14}$ The effects of sedentary behavior are detrimental to participants who obtained estimated sitting time of $\geq 6$ hours $x<3$ hours/day, $O R=1.17 ; 95 \% \mathrm{Cl} 1.11-1.24$, as this finding is associated with a higher mortality rate in men due to cardiometabolic disease indicators, thus, the results of this research project can be classified as health risk factors. ${ }^{30}$

\section{CONCLUSIONS}

The findings of the current study revealed that there are different working environments in the Brazilian Military Police that vary according to the role occupied by the law enforcement officer, which can positively or negatively impact the physical activity level and sedentary behavior of police officers both on and off duty. The result of the comparison of physical activity and inactivity levels showed that there are differences between overt and specialized patrol officers. Approximately half of the participants were found to have sedentary behavior, justified by their adopted lifestyle, unfavorable work environment and physical activity obstacles, which put them at risk of developing cardiometabolic diseases. Regarding such obstacles, it is worth emphasizing that this study has limitations regarding the collection of information about physical activity obstacles among military police officers while off duty and on duty, aspects that may be considered in future research. In this study, we also noted that 
the variables of specialized military police officers have factors that are more favorable to health than those of overt patrolling agents. To enable professionals from both areas to reduce the health risks arising from sedentary behavior, we suggest encouraging these officers to change their behavior by acquiring healthy habits and a more active lifestyle, with specific programs and tools to raise awareness in this population and in other groups from the area with regard to the importance of physical exercise in health.

All authors declare no potential conflict of interest related to this article

AUTHORS' CONTRIBUTIONS: Each author made significant individual contributions to this manuscript. AFF: preparation of the entire research project, writing, selection of participants and collection of data, data review and analysis, editing, statistical analysis, discussion of results and execution of the revision; ELA: revision and correction analysis; MV: editing, revision and tabulation of data; RLR: critical review, text analysis and writing; DSB: intellectual concept and revision; AFJ: guidance for the preparation of the project and study design, selection of participants and collection of data, discussion of results, intellectual concept, contribution in the conception and editing and revision. All authors reviewed and approved the final version of the manuscript

\section{REFERENCES}

1. Minayo MC, Souza ER, Constantino P. (coords). Missão prevenir e proteger: condições de vida, trabalho e saúde dos policiais militares do Rio de Janeiro [online]. Rio de Janeiro: FIOCRUZ, 2008. 328 p.

2. Jesus GM, Jesus EF. Nível de atividade física e barreiras percebidas para a prática de atividades físicas entre policiais militares. Rev Bras Cienc Esporte [online]. 2012 [acesso em 2017 out 3]; 34(2):433-8. Disponível em: http://www.scielo.br/pdf/rbce/v34n2/a13v34n2.pdf

3. Nahas MV. Atividade física, saúde e qualidade de vida: conceitos e sugestões para um estilo de vida ativo. 6. ed. Londrina: Midiograf, 2013.

4. Ekelund U, Steene-Johannessen J, Brown WJ, Fagerland MW, Owen N, Powell KE, et al. Does physical activity attenuate, or even eliminate, the detrimental association of sitting time with mortality? A harmonised meta-analysis of data from more than 1 million men and women. Lancet. 2016;388(10051):1302-10.

5. González K, Fuentes J, Márquez JL. Physical inactivity, sedentary behavior and chronic diseases. Korean J Fam Med. 2017;38(3):111-5.

6. Violant JM, Fekedulegn D, Hartley TA, Andrew ME, Charles LE, Mnatsakanova A et al. Police trauma and cardiovascular disease: association between PTSD symptoms and metabolic syndrome. Int J Emerg Ment Health. 2006;8(4):227-37

7. Franke WD, Ramey SL, Shelley MC. Relationship between cardiovascular disease morbidity, risk factors, and stress in a law enforcement cohort. J Occup Environ Med. 2002;44(12):1182-9.

8. Brasil. Manual de Educação Física Policial Militar: uma proposta de vida saudável. Mato Grosso: PMMT. MP-01-07-PM. 1. ed. Cuiabá: SEEL; 2007.

9. Zorec B. Anthropometric characteristics in police officers. J Crim Justice Secur. 2001;1:26-35.

10. Scott O. Physical fitness training for police officers. Law and Order. 2001;49(6):75-7.

11. Brasil. Ministério da Defesa Exército Brasileiro Estado-Maior do Exército. Manual de campanha EB20-MC-10.350. Treinamento físico militar. 4. ed. Brasília, DF: Egceef; 2015.

12. Pollock ML, Wilmore JH. Exercícios na saúde e na doença. Avaliação e prescrição para prevenção e reabilitação. 2. ed. Rio de Janeiro: Medsi, 1993.

13. Alvarez BR, Pavan AL. Alturas e comprimentos. In: Petroski EL, (ed.). Antropometria: técnicas e padronizaçōes. 3. ed. Blumenau: Nova Letra, 2007. p. 31-44

14. Haskell WL, Lee IM, Pate RR, Powell KE, Blair SN, Franklin BA, et al. Physical activity and public health: updated recommendation for adults from the American College of Sports Medicine and the American Heart Association. Med Sci Sports Exerc. 2007;39(8):1423-34.

15. Craig CL, Marshall AL, Sjöström M, Bauman AE, Booth ML, Ainsworth BE, et al. International Physical Activity Questionnaire: 12-country reliability and validity. Med Sci Sports Exerc. 2003;35(8):1381-95.
16. Katzmarzyk PT, Church TS, Craig CL, Bouchard C. Sitting time and mortality from all causes, cardiovascular disease, and cancer. Med Sci Sports Exerc. 2009:41(5):998-1005.

17. Wijndaele K, Brage S, Besson H, Khaw KT, Sharp SJ, Luben R, et al. Television viewing time independently predicts all-cause and cardiovascular mortality: the EPIC Norfolk study. Int J Epidemiol. 2011;40(1):150-9

18. Owen N, Healy GN, Matthews CE, Dunstan DW. Too much sitting: the population health science of sedentary behaviour. Exerc Sport Sci Rev. 2010;38(3):105-13.

19. Sassen B, Cornelissen VA, Kiers H, Wittink H, Kok G, Vanhees L. Physical fitness matters more than physica activity in controlling cardiovascular disease risk factors. Eur J Cardiovasc Prev Rehabil. 2009;16(6):677-83.

20. Nabeel I, Baker BA, McGrail MP Jr, Flottemesch TJ. Correlation between physical activity, fitness, and musculoskeletal injuries in police officers. Minn Med. 2007;90(9):40-3.

21. Flegal KM, Carroll MD, Kit BK, Ogden CL. Prevalence of obesity and trends in the distribution of body mass index among US adults, 1999-2010. JAMA. 2012;307(5):491-7.

22. Ramey SL, Perkhounkova Y, Moon M, Budde L, Tseng HC, Clark MK. The effect of work shift and sleep duration on various aspects of police officers' health. Workplace Health Saf. 2012;60(5):215-22.

23. da Silva Ferreira DK, Bonfim C, Augusto LG. Factors associated with the lifestyle of military police officers. Ciênc Saude Colet. 2011;16(8):3403-12.

24. Shiozaki M, Miyai N, Morioka I, Utsumi M, Hattori S, Koike H, et al. Job stress and behavioral characteristics in relation to coronary heart disease risk among Japanese police officers. Ind Health. 2017;55(4):369-80.

25. Thayyil J, Jayakrishnan TT, Raja M, Cherumanalil JM. Metabolic syndrome and other cardiovascular risk factors among police officers. N Am J Med Sci. 2012;4(12):630-5.

26. Sörensen L, Smolander J, Louhevaara V, Korhonen O, Oja P. Physical activity, fitness and body composition of Finnish police officers: a 15-year follow-up study. Occup Med (Lond). 2000;50(1):3-10.

27. Gu JK, Charles LE, Burchfiel CM, Fekedulegn D, Sarkisian K, Andrew ME. Long work hours and adiposity among police officers in a US northeast city. J Occup Environ Med. 2012;54(11):1374-81.

28. Kyröläinen $H$, Häkkinen $K$, Kautiainen $H$, Santtila M, Pihlainen $K$, Häkkinen A. Physical fitness, BMI and sickness absence in male military personnel. Occup Med (Lond). 2008;58(4):251-6.

29. Lagestad P, van den Tillaar R. A comparison of training and physical performance of police students at the start and the end of three-year police education. J Strength Cond Res. 2014;28(5):1394-400.

30. Patel AV, Bernstein L, Deka A, Feigelson HS, Campbell PT, Gapstur SM, et al. Leisure time spent sitting in relation to total mortality in a prospective cohort of US adults. Am J Epidemiol. 2010;172(4):419-29. 